\title{
Development of the Digestive Organs and some Physiological Aspects in Liquid Fed Goats
}

\author{
Tsutomu FuJiHARA* \\ Faculty of Agriculture, Nagoya University, Nagoya-shi 464
}

(Received June 1, 1974)

\begin{abstract}
Goats were fed a liquid diet for 12 months or more, and the following results were obtained. 1. The goats possibly grow at almost the same rate as the normal goats, but there are some factors to restrict the feed consumption in the liquid feeding. 2. It is apparent that the abomasum is larger than that of the weaning type. The body-weight ratio of the abomasum was $0.5 \sim 0.7$, and this figure is very comparable with that of the suckling type. 3. When the caudo-ventral sac of the rumen was removed at the early stage of the life, the reticulum and the dorsal sac of the rumen were enlarged compensationally. 4. The concentration of post-prandial blood glucose was $70 \sim 80 \mathrm{mg} / 100 \mathrm{~m} l$, and this value is almost the same as that of mono-gastric animals. 5. The ruminal and blood concentrations of VFAs were very low, and this suggests that the ruminal fermentation is scant in the liquid-fed goats.
\end{abstract}

According to TAMATE et al. ${ }^{1}$, the development of the reticulo-rumen of dairy calves after weaning is stimulated by the shape and the composition of feedstuffs given, and also by the fermented products in the rumen. TAMATE et al. ${ }^{2}$ further reported that the weight of the reticulo-rumen of suckling dairy calves does not increase even at 8 months after birth.

In the present experiment, the development of the digestive organs of goats, a part of whose rumen was removed, was examined when they were maintained by a long term liquid feeding.

\section{Experimental}

Animals and feeding procedure

Four female and 2 castrated male Japanese Saanen goats, 10 to 15 days old and weighing $5 \sim 6 \mathrm{~kg}$, were used in the present experiment. The goats were individually housed in pens with wire floor during the entire experimental period. A commercial calf-milk containing $2 \%$ of fibrous materials was fed throughout the experimental period of 24 months in one case and of 12 months in the others. The chemical composition of the diet is shown in Table 1. One-half of a dairy. ration, which is $1 \sim 2 \%$ of body weight based on the recommendation of $\mathrm{NRC}^{3 /}$ for sheep, was suspended in warm water and given to the goats from a bucket twice a day at 9:00 a.m. and 17:00 p. m.. The animals were weighed once a week before the morning feeding.

\section{Surgical operation for removal of rumen compartment}

Five of 6 experimental animals were operated for removal of rumen compartment at 10 to 15

* Present address: Faculty of Agriculture, Kagawa University, Kagawa ken 761-07.

Jap. J. Zootech. Sci., 46, (5): 283-289. 
Fujihara

Table 1. Composition of experimental diet*

\begin{tabular}{lc}
\hline \hline Crude protein & 27.0 (\%) \\
Crude fat & 10.5 \\
Crude fiber & 2.0 \\
Crude ash & 12.0 \\
Calcium phosphate & 0.2 \\
Nitrogen free extract & 48.3 \\
\hline
\end{tabular}

* Commercial calf-milk produced by Nihonnosan Co. Ltd. Nagoya shi. Additives (per $100 \mathrm{~g}$ of diet); procain penicillin $2000 \mathrm{IU}$, and other antibiotics $5-6 \mathrm{mg}$

days after birth. After fasting for 24 hours, the animals were anesthetized by an intravenous injection of $10 \mathrm{mg}$ of sodium pentobarbital per kilogram of body weight and placed on an operating table right side down. An about $15 \mathrm{~cm}$ longitudinal incision was made through the left side skin of the body at approximately $5 \mathrm{~cm}$ posterior to the last rib. The muscles and peritoneum were dissected and the reticulo-rumen was drawn out from the abdominal cavity. The caudo-ventral sac and a part of the dorsal sac of the rumen were cut off, and the incision was sutured. The residual part of the reticulo-rumen was withdrawn into the abdominal cavity, and the peritoneum and the abdominal wall were sutured. The animals were fasted for 24 hours after the operation. Thereafter the animals were gradually accustomed to the diet.

\section{Post-mortem observation and chemical analysis}

Goat $B$ was slaughtered by bleeding at the end of the experimental feeding period for 24 months, and the other goats for 12 months. After the digestive organs were anatomically observed, reticulo-rumen, omasum and abomasum, which were all empty, and liver and spleen were weighed. Jugular blood was sampled before and after the morning feeding on the day of slaughter. Ammonia concentration of the rumen fluid was determined by the aeration method ${ }^{4)}$. Blood glucose was analyzed by the method of SomoGY ${ }^{5}$ ), and VFAs in both the rumen fluid and the blood were analyzed by the method of Conway and DowneY6).

\section{Results and Discussion}

Feed consumptions and growth curves of the goats are shown in Figures 1 and 2. Compared to the standard growth of Japanese Saanen goats indicated by NAGASAwA ${ }^{7}$, the growth of Goat A (castrated male) during 6 months after birth was very fast, and thereafter it became slow. The growth of Goat B (female) was almost comparable with the standard growth of female goats on general feeding. As shown in Figure 2, until 8 months of age feed intake of Goat B was somewhat more than that of Goat $A$, since the appetite in Goat $A$ was depressed sometimes. In Goat $\mathrm{C}, \mathrm{D}$ and $\mathrm{F}$, the growth rate became very slow after 5 or 6 months of age, and this is considered to be a reflection of the low feed intake as shown in Figure 2. These growth rates, however, were almost comparable with the result of $\mathrm{HAmADA}^{8)}$ using gastrectomized goats fed a solid diet. The feed intake was significantly lower in Goat $\mathrm{E}$ than in the other goats, and consequently an increase of body weight in Goat $\mathrm{E}$ was very low, being about one-half the standard growth. The appetite in Goat $\mathrm{E}$ was very often depressed. As shown in Figure 2, the feed intake increased 


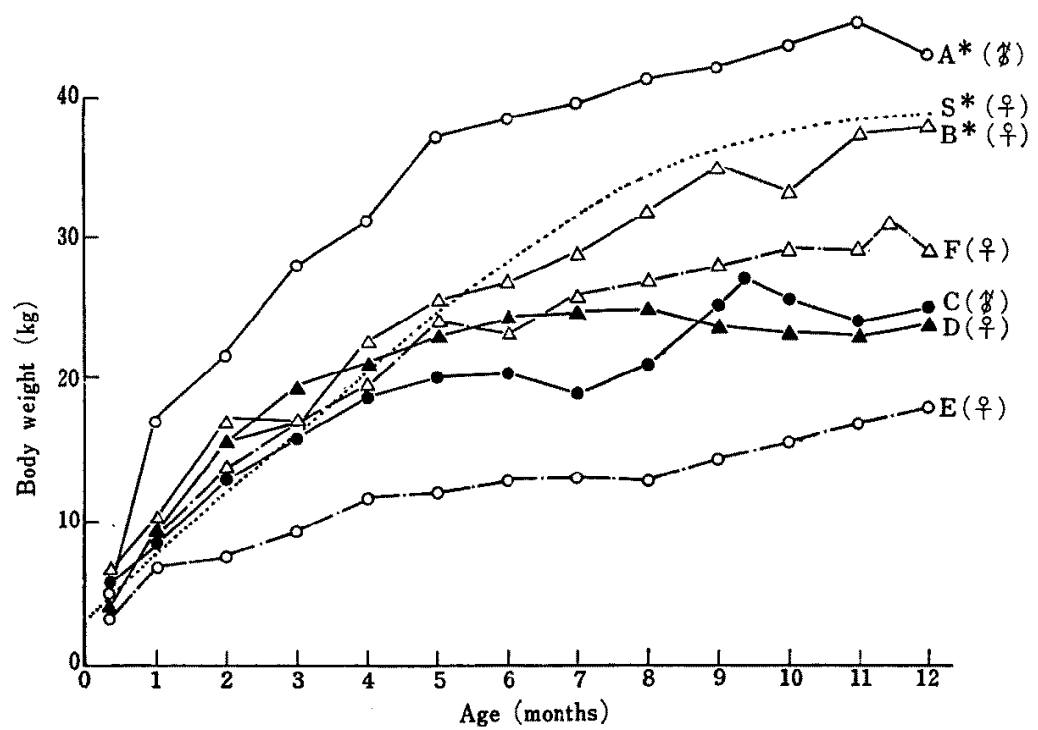

Fig. 1. Growth curves of goats

* A-F : Experimental goat. *S: Standard growth by NAGASAWA"

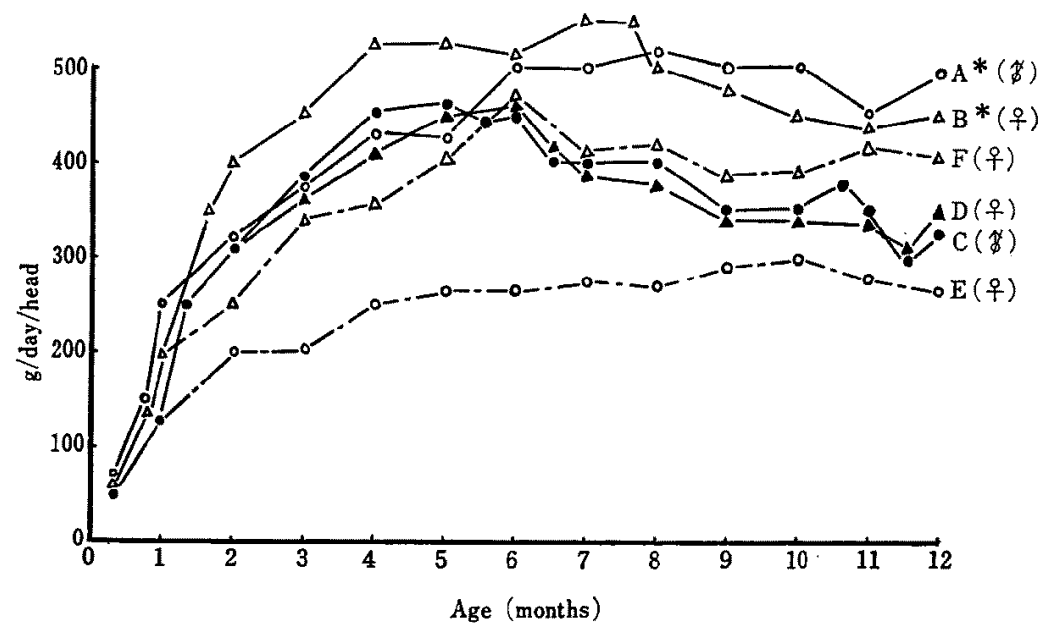

Fig. 2. Changes in feed consumption of goats.

*A-F: Experimental goat.

up to 6 months of age (except for Goat F) and thereafter it became constant or even decreased. This fact suggests that there are some factors to restrict feed intake in the liquid feeding of ruminants. Such limiting factors in the liquid feeding are necessary to be investigated fundamentally.

Goat $\mathrm{A}$ was liquid-fed for 12 months but its ruminal compartment was not removed. As shown in Figure 3, the dorsal sac of the rumen reached the point opposite the fifth lumbar vertebra, while, according to TAMATE ${ }^{9)}$, the caudal end of the dorsal sac remains at the point opposite the fourth lumbar vertebra in a suckling type. Such an extention of the rumen in Goat A may be due to the prolonged liquid feeding as suggested by TAMATE $^{9)}$. The omasum was small, and 


\section{Fujihara}
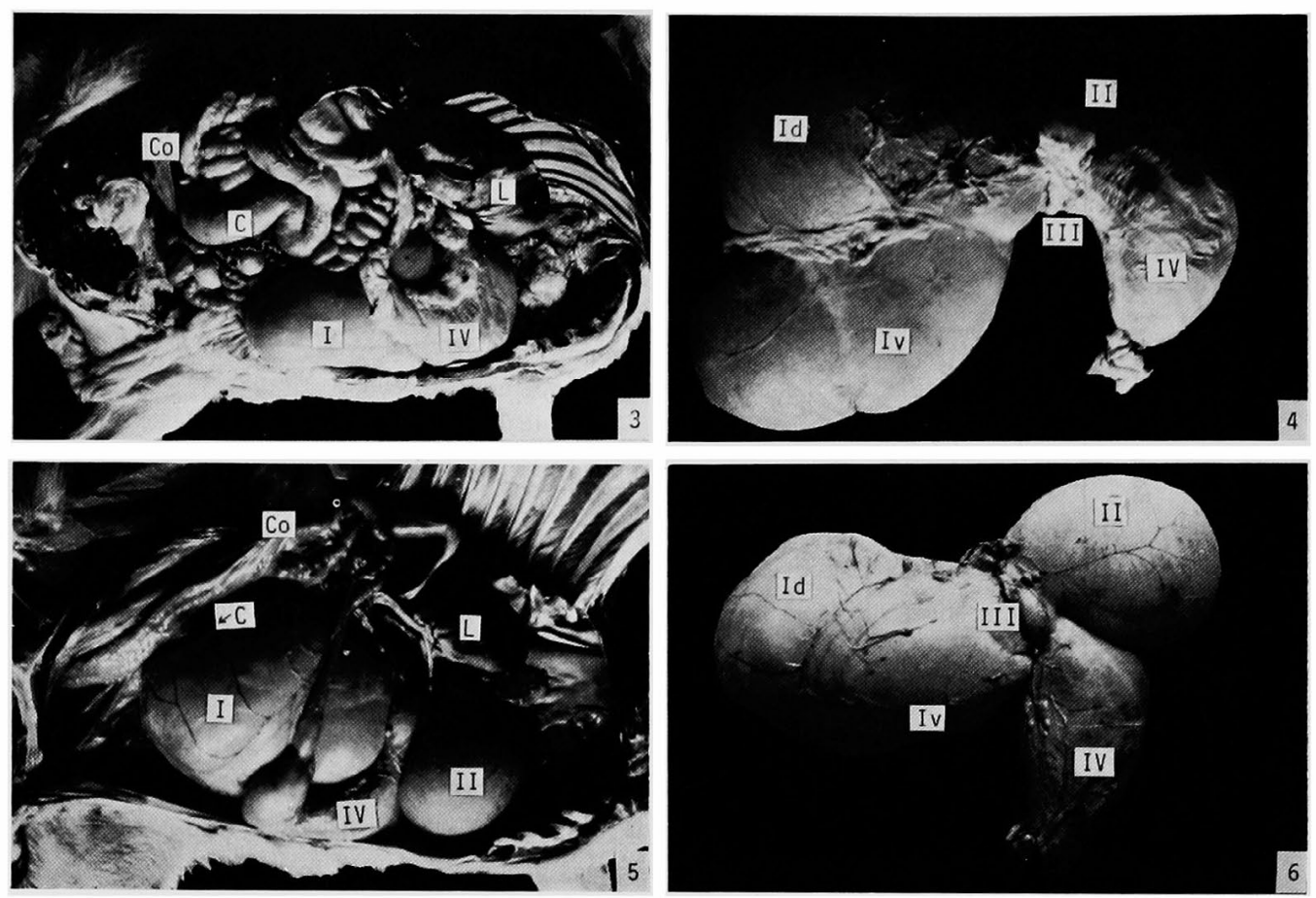

\section{Abbreviations}

I: rumen, II: reticulum, III: omasum, IV: abomasum, Id: dorsal sac, Iv: ventral sac.

L: liver, C: cecum, Co: coils of colon.

Explanation of plate

Fig. 3. Right-side view of abdominal cavity in Goat A

Fig. 4. Stomach in Goat A

Fig. 5. Right-side view of abdominal cavity in Goat B

Fig. 6. Stomach of Goat B

the abomasum and the cecum were very large. The coils of the colon were cylindrical, likely those of the suckling type reported by TAMATE ${ }^{9)}$. The liver migrated to the right side, and this is in contrast to the suckling type ${ }^{9)}$, in which the liver remains at the left side. The papilla of the rumen barely developed. There were many hairs in the reticulum and some sands in the fundic portion of the abomasum along the greater curvature. The rumen was slightly larger than that of the goats fed milk for $53 \sim 72$ days observed by TAMATE ${ }^{9,10)}$, and such a difference of the rumen growth between the present and the TAMATE's studies may be due to the duration of the liquid feeding. The growth of the rumen observed in this study, however, obviously differed from that of the weaning type ${ }^{9)}$.

As shown in Figures 5 and 6, the rumen of Goat B, which was operated and liquid-fed for 24 months, had no caudo-ventral sac. However, the dorsal sac developed extensively and laid on the abdominal floor ventrally, and its dorsal curvature reached the vertical line between the third and fourth lumbar vertebras. The reticulum was enlarged and its front end reached the sixth intercostal space. The omasum was small, and the abomasum and the cecum were very large. The fundus of the abomasum squeezed itself between the rumen and the reticulum. This situation is not general in the weaning type ${ }^{9)}$. The liver already migrated to the right side of the body. 


\section{Some Aspects in Liquid Fed Goats}

The coils of the colon were cylindorical just like that of Goat A, and migrated forward. The papillae of the rumen and folds of the reticulum barely developed.

The development of the digestive organs in Goat C, D, E and F was anatomically the same as that in Goat B. The rumen of Goat C was more enlarged than that of Goat B, that is, the dorsal sac reached the point opposite the fifth lumbar vertebra. There were many hairs and hair balls in the rumen of Goat $\mathrm{C}$, and there is a possibility that these hairs balls might stimulate the enlargement of the rumen.

It is probable that the enlarged both reticulum and dorsal sac of the rumen might compensate for the ventral sac removed, and the dorsal sac occupied the space generally occupied by the ventral sac in the intact animals. The omasum was not enlarged, but some changes in the form of the intestine were observed and these changes might be resulted from a locational alternation of the stomach.

Wet organ weight and body-weight ratio of the organs are indicated in Table 2. Even when a part of the rumen was removed, no regeneration of fore-stomach was observed and the abomasum developed remarkably. The body-weight ratio of the reticulo-rumen except for Goat $\mathrm{C}$ was 1.21 1.96, and these values were almost similar to those reported by TAMATE et al. ${ }^{1)}$ with 12 -week old calves fed whole milk, concentrates and hay. In Goat $\mathrm{C}$ the body-weight ratio of the reticulorumen was 0.74 , and the body-weight ratio of the abomasum was $0.49 \sim 0.70$ in all goats tasted. These figures were almost similar to those reported by TAMATE et al. ${ }^{1}$ with whole milk fed 12-week old calves. Wet weight of the liver and spleen and their body-weight ratios were not different from those of the normal goat ${ }^{11}$. It is assumed from these results that the suckling type of the digestive organs could be maintained for a long time by the continuing liquid feeding, and also that the reticulo-rumen in most cases was developed by the long term liquid feeding, although little microbial fermentation occurred in the rumen as discussed later.

The concentrations of blood glucose, blood VFAs, ruminal ammonia and ruminal VFAs at $1_{2}$ months of age (at 24 months in Goat B) are shown in Table 3. Young et al. ${ }^{11}$ reported that the post-absorptive blood glucose concentration in calves fed milk for 105 days was $50 \sim 60 \mathrm{mg} / 100 \mathrm{~m} l$, and LUPIEN et al. ${ }^{12)}$ reported the blood glucose concentration of $85 \mathrm{mg} / 100 \mathrm{ml}$ in 30 -week old gastrectomized and fasted calves. According to our unpublished data, the post-prandial concentration of blood glucose was $72 \sim 98 \mathrm{mg} / 100 \mathrm{ml}$ in 3-month old whole milk fed kids. In the present experiment, the concentration of blood glucose in post-absorptive and post-prandial conditions was

Table 2. Wet organ weight and body-weight ratios of organs

\begin{tabular}{|c|c|c|c|c|c|c|}
\hline Goat & A & $\mathrm{B}$ & $\mathrm{C}$ & $\mathrm{D}$ & $\mathrm{E}$ & $\mathrm{F}$ \\
\hline \multicolumn{7}{|l|}{ Body weight } \\
\hline & 41.3 & 36.3 & 22.2 & 24.2 & 17.5 & 29.0 \\
\hline \multicolumn{7}{|l|}{ Wet weight } \\
\hline Reticulo-rumen & $713(1.73)$ & $712(1.96)$ & $166(0.74)$ & $295(1.21)$ & $291(1.66)$ & $440(1.51)$ \\
\hline Omasum & $41(0.10)$ & $31(0.09)$ & $26(0.12)$ & $23(0.10)$ & $13(0.07)$ & $34(0.13)$ \\
\hline Abomasum & $235(0.56)$ & $204(0.56)$ & $110(0.49)$ & $152(0.62)$ & $124(0.70)$ & $156(0.53)$ \\
\hline Liver & $635(1.53)$ & $814(2.24)$ & $310(1.35)$ & $375(1.54)$ & $386(2.20)$ & $834(1.49)$ \\
\hline Spleen & $125(0.30)$ & $63(0.17)$ & $44(0.20)$ & $66(0.27)$ & $62(0.35)$ & $84(0.29)$ \\
\hline
\end{tabular}

Goat B-F were operated for removal of the rumen. Goat B was 24 months old and the others 12 months old. Values in parenthesis show the body-weight ratios of the organs 
Table 3. Concentrations of blood glucose, blood VFA, Ruminal ammonia and ruminal VFA, indicated as $\mathrm{mg} / 100 \mathrm{~m} l$

\begin{tabular}{|c|c|c|c|c|c|c|}
\hline \multirow{3}{*}{ Goat } & \multicolumn{4}{|c|}{ blood } & \multicolumn{2}{|c|}{ ruminal } \\
\hline & \multicolumn{2}{|c|}{ glucose } & \multicolumn{2}{|c|}{ VFA } & ammonia & VFA \\
\hline & B. F* & A. $F^{* *}$ & B. F & A. $F$ & 4 hours after & morning feeding \\
\hline A & 44 & 70 & 1.0 & 1. 1 & 14.0 & 1.0 \\
\hline B & 51 & 21 & 1.0 & 1.1 & 10.0 & 0.8 \\
\hline $\mathrm{C}$ & 58 & 83 & 1.0 & 1.0 & 7.0 & 0.9 \\
\hline $\mathrm{D}$ & 52 & 83 & 1.0 & 1.0 & 10.0 & 1.0 \\
\hline $\mathrm{E}$ & 55 & 81 & 1.0 & 1.3 & 6.0 & 1.0 \\
\hline $\mathbf{F}$ & 54 & 83 & 0.7 & 1.3 & 13.0 & 1.1 \\
\hline
\end{tabular}

* Before feeding. *** After feeding

$44 \sim 58 \mathrm{mg} / 100 \mathrm{ml}$ and $70 \sim 83 \mathrm{mg} / 100 \mathrm{ml}$, respectively. The result in the present experiment was almost comparable to the results of Yovng et al. ${ }^{11)}$ and LuPIEN et al. ${ }^{12}$. Suckling ruminants digest milk in the abomasum and lower digestive tracts, thus glucose is considered to be a main energy source in the suckling ruminants. From these results the digestive process in liquid fed ruminants is almost the same as that of mono-gastric animals. HAMAdA ${ }^{8)}$ reported, however, that postprandial serum glucose was $119 \mathrm{mg} / 100 \mathrm{~m} l$ in the kids whose fore-stomach was completely removed, and he suggested that long-term adaptation of the ruminant to a single stomached digestive system may change hormonal and enzymatic activities in glucose metabolism:

As shown in Table 3 , the post-prandial blood VFA concentration was $2.0 \sim 2.3 \mathrm{mg} / 100 \mathrm{ml}$, being less than' one-half the value observed in adult goats $(2.2 \sim 3.2 \mathrm{mg} / 100 \mathrm{ml})^{13}$. According to SHibATA ${ }^{13)}$, ruminal VFA concentration was $207 \sim 245 \mathrm{mg} / 100 \mathrm{ml}$ before feeding in normal goats, whereas in this study ruminal VFAs were scarecely detected. Ruminal ammonia concentration was $6 \sim 14 \mathrm{mg} / 100 \mathrm{ml}$, which was about one-half the value of normal goats ${ }^{14)}$. It can be concluded from these results that when the goats were fed a liquid diet even for a long period, microbial fermentation in the rumen is very limited, and consequently the main energy source is considered to be glucose instead of VFAs.

The author expresses a deep appreciation to Dr. H. TAMATE for his valuable suggestions and helpful assistance for anatomical observation.

This work was carried out from April 1970 to March 1972 by efforts of the members in Laboratory of Animal Nutrition, Nagoya University. The members were as follows: Y. AsAKURA, Y. Karasawa, T. Koh, H. Kondo, T. Maruyama, S. Mizuno, T. Ohno, J. Okumura, K. Lee, F. Shibata, H. Shimozawa, T. Sugimoto, I. Tasaki, H. Ueda and H. Yokota.

\section{References}

1) Tamate, H., A. D. McGilliard, N. L. Jacobson, and R. Getty, J Dairy Sci 45: 408-420 1962.

2) Tamate, H., A. D. McGilliard, N. L. Jacobson, and R. Getty, Tohoku J Agr Res 14: 171193. 1964.

3) National Academy of Sciences, Nutrient Requirements of Sheep. NAS-NRC Publication 504, Revised 1957. Washington, D.C. 1962.

4) Hawk, P.B., B. L. Oser, and W.H. Summerson, Practical Physiological Chemistry 889. McGraw 
Hill Co. New York. 1954.

5) Sомоgy, M:, J Biol Chem 195: 19-23. 1952.

6) Conway, E. J., and M. Downey, Biochem J 47: iv. 1950.

7) Nagasawa, H., Chikusan Daijiten (K. Sasaki ed.) 939-940. Yôkendo Co. Tokyo, 1964. (in Japanese)

8) Hamada, T., J Dairy Sci 56: 474-483. 1973.

9) Tamate, H., Tohoku J Agr Res 7: 209-219. 1956.

10) Tamate, H., Tohoku J Agr Res 8: 65-77. 1957.

11) Young, J. W., E. O. Otchere, A. Trenkle, and N.L. Jacobson, J Nutr 100: 1267-1273. 1970.

12) Lupien, P. J., F. Sauer, and G. V. Hatina, J Dairy Sci 45: 210-217. 1962.

13) Shibata, F., Memoirs of the Laboratory of Animal Nutrition, Nagoya University, No. 3, 7-23. Nagoya University. Nagoya. 1963.

14) Fujihara, T., and I. TAsaki, Jap J Zootech Sci 42: (supplement) 31-32. 1970. (in Japanese)

\section{長期代用乳給与によるヤギ消化管の発達と}

\section{その生理的機能について}

藤原勉

名古屋大学農学部, 名古屋市 464

本研究は長期間代用乳で飼育したャギの成長および消 化管発達の様相を検索することを目的として行われた。 生後10〜15日齿合のヤギ 6 頍供試したが, そのうち 5 頭 は供試時に第一胃腹後盲聚を切除した。供試ヤギは金絧 床の個室内で 12 力月（1 例は 24 力月）飼育されたが， 全期間にわたり代用乳のみを給与した，その結果，次の ことが明らかになった。1. 実験期間中に食欲の減退す ることもあったが，一般にはとの成長速度は通常飼育の ものと大差はなかった、2. 第四胃の発達恃著しく、その
体重に対する比萆は 0.5〜0.7で，哺乳中のそれと類似し ていた．３．第一胃腹後盲露切除ヤギでは，第二胃㧍よび 第一胃背露が代償的に発達した。.4.食後 2 時間の血中グ

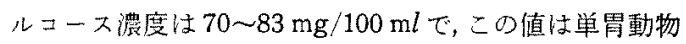
のそれと類似していた．5．血中および第一胃液中の VFAs 漂度は非常に低く，このことは代用乳給与ヤギの 第一胃内発醉がほとんど行われないことを意味してい 万. 